\title{
Speech is Silver, Silence is Golden: The Cultural Importance of Silence in Japan
}

\author{
Sally Jones
}

\section{Abstract}

In Japan, there exists a strange dichotomy. On the one hand, it is a noisy place: the constant announcements in the train stations and shopping centres, the loud cries of shopkeepers greeting customers to their stores, the hustle and bustle of the busy streets. On the other hand, the Japanese value silence. It might seem odd that silence is valued in a place where such a cacophony exists, but silence in everyday interaction is a vital form of non-verbal communication for the Japanese. This is because silence (like speech) conveys emotions, shows respect, creates personal distance, avoids conflict and even negates the meaning of verbal messages. The purpose of this paper is to examine silence as a communicative act in a cultural context. Four culturally salient and highly valued dimensions of Japanese silence will be examined, as well as the role of silence in intercultural communication between the Japanese and other cultures. In examining silence, the author suggests that silence is merely more than just a void in communication, but it is also a window into Japan's underlying cultural beliefs and values.

\section{Introduction}

In a 2007 paper on the cultural importance of silence, Takie Lebra identified four dimensions of Japanese silence - truthfulness, social discretion, embarrassment and defiance. ${ }^{1}$ This paper will analyse silence through these dimensions. Notably, due to its ambiguous nature, cultural outsiders can easily misinterpret silence. Thus, this paper will also seek to examine the source of this misinterpretation, which lies primarily in the linguistic and cultural differences between cultures. An understanding of these differences is key to effective cross-cultural communication.

\footnotetext{
1 Lebra, Takie. "The Cultural Significance of Silence in Japanese Communication". Ed. Takie Lebra. Identity, gender, and status in Japan: collected papers of Takie Lebra. Folkestone, Kent, U.K.: Global Oriental, 2007.
} 


\section{Four Dimensions of Japanese Silence}

\section{Truthfulness}

Historically in Japan, silence has been associated with truthfulness. This belief originated in Zen Buddhism, where the spoken word was discouraged and silence was encouraged because it was believed that enlightenment could not be attained by talking about it. ${ }^{2}$ Furthermore, Buddhist chants enabled people to realise the emptiness of words. This belief is perhaps best exemplified by the concept of ma (間). One of the Japanese words for silence, chinmoku, has a strong connection with $m a .^{3}$ In both traditional and modern-day Japanese music, ma that refers to "the 'space' or silence between notes... this notion of space is not just about musical timing, but also concerns the idea that music is both the notes played and the silence in between". ${ }^{4}$

Moreover, Japanese proverbs, expressions and poetry warn against the use of the spoken word. The proverbs kiji mo nakazuba utaremai ("silence keeps one safe") and mono ieba kuchibiru samushi aki no kaze ("it is better to leave many things unsaid") highlight this belief. These proverbs highlight the Japanese belief that verbal expression cannot be trusted and has consequences for the speaker. In a modern day context, this dimension of silence is relevant in politics. Even with the introduction of speech-giving in the late nineteenth century, Japanese politicians are still judged by virtues such as silence rather than their oratory skills, where the contrary is mostly true in the Anglo-West. ${ }^{7}$

On the intra-personal level, truthfulness is related to the idea of a person's inner (private) and outer (public) realms. The outer realm of a person concerns one's outer body, which includes one's speech organs and verbal expression, while silence is associated with the inner realm, which the Japanese equate with truthfulness. ${ }^{8}$ This socio-psychological idea is central to the Japanese mind-set. Unlike the English language, the Japanese word for 'mind' does not

2 Wright, Dale S. Philosophical Meditations on Zen Buddhism. Cambridge: Cambridge University Press, 2000, p.94.

3 Hasegawa, Tomohiro, and William B. Gudykunst. Silence in Japan and the United States. Journal of CrossCultural Psychology 1998 29: 668-682, p.669.

4 Deal, William E. Handbook to life in medieval and early modern Japan. New York: Infobase Publishing, 2006, p. 268.

5 Kiji mo nakazuba utaremai (雉も鳴かずば打たれまい): literally translated, “If the pheasant did not sing, it would not have been attacked".

6 Mono ieba kuchibiru samushi aki no kaze (もの言えば/唇寒し/秋の風): literally translated, “If something is said, the lips become cold like the autumn wind". This haiku was written by Edo poet, Bashō Matsuo.

7 Lebra 2007 op. cit., p.117.

8 Maynard, Senko K. Japanese communication: language and thought in context. Honolulu: University of Hawaii Press, 1997, p.154. 
invoke notions such as emotion and perception. ${ }^{9}$ Instead, concepts such as belly (hara) and heart (kokoro) are used to describe this. ${ }^{10}$ Kokoro (one's true feelings) originate from within the inner realm and silence is hence associated with the truthful inner realm. The Japanese believe in a lower amount of verbal expressiveness due the wide-held belief that the inner self should be hidden as much as possible. ${ }^{11}$

\section{Social Discretion}

This dimension of silence refers to the use of silence to improve one's social standing. A prime example is a person's politeness. In 1978, Brown and Levison formulated a socio-psychological theory called 'Politeness Theory'. ${ }^{12}$ This hypothesis dictated that every individual has a public self-image, referred to as 'face'. ${ }^{13}$ There are two types of face: 'negative face' is the desire to act freely whereas 'positive face' is the desire to be liked by other people. ${ }^{14}$ This commutated in the idea of 'Face-Threatening Acts' (hereafter FTA); any (verbal) act that potentially threatens either the speaker's or the addressee's face. ${ }^{15}$ Politeness hence involves the maintenance of one's face and the avoidance of harming the addressee's face.

Silence is one FTA technique utilised by the Japanese because there is always a threat to an individual's positive or negative face through the verbal interaction between an addressee and a speaker. However, the degree of FTA is determined by a number of factors, including social distance and the manner of the FTA. ${ }^{16}$ Consequently, social discretion through silence is an example of a "don't do the FTA" strategy. This strategy involves maintaining the positive face of the addressee through the speaker's avoidance of disagreement with the addressee. ${ }^{17}$ For instance, students may deny the teacher's request to answer a question in class. A possible explanation is the "don't do the FTA strategy" whereby students avoid threatening the teacher's positive face or losing face themselves by not answering questions. Thus, silence in this case is the avoidance of doing

\footnotetext{
9 Johnson M.D., Frank A. Dependency and Japanese Socialization: Psychoanalytic and Anthropological Investigations into Amae. New York, London: New York University Press, 1993, p.227.

10 Ibid.

11 Barlund, Dean C. Public and Private Self in Japan and the United States: Communicative Styles of Two Cultures. Tokyo: The Simul Press, 1975, p.35.

12 Brown, Penelope, and Stephen C. Levinson. Politeness: some universals in language usage. Cambridge, New York: Cambridge University Press, 1987.

13 Sifianou, Maria. "Silence and politeness". Ed. Jaworski, Adam. Silence: interdisciplinary perspectives Berlin, New York: Mouton de Gruyter, 1997, p.66.

14 Brown and Levinson op. cit., p.62.

15 Sifianou op. cit., p.66.

16 Sifianou op. cit., p.68.

17 Brown and Levison op. cit., p.72.
} 
a certain communicative act. In contrast to the association between truthfulness and silence, the speaker hides their misgivings and disagreements from the hearer in polite and socially acceptable silence.

\section{Embarrassment}

In Japan, silence is an indicator of the degree of intimacy in private relationships. In particular, silence in this case is to provide a rapport between husband and wife. It is expected that the husband will exhibit some emotional distance with his spouse through the use of silence. ${ }^{18}$ This is due in part to the belief in Japan that silence is characteristically associated with men. ${ }^{19}$ Despite the apparent emotional distance between husband and wife, this relationship is instead judged on whether the couple can understand one another without words. The verbal communication of their affection is considered to be highly embarrassing so nonverbal communication of this affection is preferred by couples. ${ }^{20}$ This is in part due to a Japanese ideal called ittai, which is the belief that husband and wife are one entity. ${ }^{21}$ In other words, it is culturally expected that husband-wife relationships place important emphasis on non-verbal communication. This includes the Zen Buddhist concepts of ishin-denshin (communication through telepathy) and enryo-sasshi (intuitive sensitivity). ${ }^{22}$ Moreover, this function of silence is not limited to only the private relationship between husband and wife, but is also an indicator of the rapport in any private relationship, including business associates and close friends. ${ }^{23}$

The role of non-verbal communication in relationships highlights the significance of the uniquely Japanese concept called haragei. Originating as a theatrical technique, the term haragei (literally "belly art" or "belly performance") is implicit communication or mutual understanding through non-verbal means (such as ishin denshin and enryo-sasshi). ${ }^{24}$ It is widely believed that the belly (located in the inner realm) is the source of a person's truthfulness. Hence

18 Lebra, Takie. Japanese Women: Constraint and Fulfillment. Honolulu: University of Hawaii Press, 1984a, p.125.

19 Ibid., p.126.

20 Lebra 2007 op cit., p.119.

21 Lebra 1984a op cit., p.125.

22 Jackson II, Ronald L. Encyclopedia of Identity. California, London, New Delhi: SAGE Publications, 2010, p.251.

23 Doi, Takei. "The Japanese Psyche: Myth and Reality". Eds. Strozier, Charles B. and Michae, Flynn. Trauma and self. London: Rowman and Littlefield Publishers, Inc., 1996, p.200.

24 Davies, Roger J., and Osamu Ikeno, eds. The Japanese mind: understanding contemporary Japanese culture. Boston: Tuttle Pub., 2002, p.103. 
only through non-verbal communication such as haragei can individuals truly understand one another. ${ }^{25}$ If one understands how to utilise haragei, silence becomes a non-verbal means of communicating one's true emotions successfully.

\section{Defiance}

In contrast to the other dimensions that help to maintain positive communication between individuals, silence in this instance is used instead to convey defiance and estrangement. To identify the dimension of silence being used, sasshi (listener's ability to guess what a person is inferring) is considered to be an important paralinguistic skill for the Japanese. ${ }^{26}$ Furthermore, defiant silence is often used in conjunction with other non-verbal communication, such as sulking, prolonged eye contact and facial expressions. ${ }^{27}$ Alongside these nonverbal gestures, if a speaker remains silent for a certain amount of time, this may indicate to the listener that the speaker is being defiant. ${ }^{28}$ Granting this, silence is still highly ambiguous because silence can have various meanings depending on context. For instance, in a school classroom setting, a student's refusal to answer a teacher's question can be considered as an act of defiance. ${ }^{29}$ However, this might also be attributed to: politeness towards the teacher, the inability to answer a question and the negative connotations associated with expressing one's opinion. Additionally, a wife may utilise defiant silence if her husband committed adultery," but it may also indicate "feminine modesty, compliance, patience, resentment, unforgiveness". ${ }^{31}$ For those unaccustomed to this highly contextualised silence (notably Anglo-Westerners), this may cause many miscommunications due to the complex nature of silence in Japan.

\section{Silence in Intercultural Communication}

This section will analyse the use of silence in intercultural communication, with particular emphasis on the perceived roles of silence in Japanese and American

\footnotetext{
25 Yamada, Haru, and Deborah Tannen. Different games, different rules: why Americans and Japanese misunderstand each other. New York, Oxford: Oxford University Press, 1997, p.17.

26 Nishida, Tsukasa. "Communication in Personal Relationships in Japan". Eds. Gudykunst, William B., Stella Ting-Toomey and Tsukasa Nishida. Communication in personal relationships across cultures. California, London, New Delhi: Sage Publications, Inc., 1996. p. 114.

27 Lebra, Takie. "Nonconfrontational Strategies for Management of Interpersonal Conflicts". Eds. Krauss, Ellis S., Thomas P. Rohlen and Patricia G. Steinhoff. Conflict in Japan. Honolulu: University of Hawaii Press, 1984 b, p.43.

28 Nishida op. cit., p.115.

29 Sifianou op. cit., p.68.

30 Lebra 2007 op. cit., p.120.

31 Lebra 2007 op. cit., p.121.
} 
cultures. An analysis was done on Japanese and American intercultural communication, and not Japanese and Australian, because there has been significantly more academic work done in the former rather than the latter.

\section{Cultural Stereotyping}

Our understanding of silence in the intercultural communication between Japanese and American English speakers has been based primarily on subjective observations rather than through empirical means. Consequently, much of the study in this area may unnecessarily reinforce cultural stereotypes of another culture, thus creating dichotomies that may not necessarily exist. ${ }^{32}$ In the instance of silence in intercultural communication, Japanese speakers are often stereotyped as being 'non-verbal' juxtaposed with the 'talkative' American stereotype. Such an assumption that people within a culture are homogeneous rather than heterogeneous is problematic. A person's attitude to silence is determined by their own internal linguistic and cultural belief system, so their perception of silence and meanings attached to silence can defy cultural norms. For instance, the perception that Japanese speakers have a preference for silence is not always true - Japanese speakers can be quite talkative. Additionally, there is variation in attitudes regarding verbal interaction between the United States' western and eastern regions, which are considered to be more talkative and less tolerant of silence, and less talkative and more tolerant of silence respectively (naturally, there are also variations in how people use silence in these regions as well). ${ }^{33}$ Stereotypes thus tend to neglect the individualistic and regional aspects within a culture.

It is important to understand the reasons for the linguistic differences in cultures that cause these perceived differences. It is also important to realise that there are cultural differences in how silence is utilised because it can cause miscommunication between parties if silence is wrongly interpreted. For instance, in an Australian university seminar setting, Japanese students may utilise silence similarly to the 'social discretion' aspect of silence mentioned previously in order to be polite. ${ }^{34}$ However, in an English-speaking environment, the Japanese speaker's use of silence may be judged unfavourably by their fellow peers and lecturers, miscommunicated as an unwillingness to participate. ${ }^{35}$ Hence, it is important to understand that there are different perceptions of silence between cultures, which need to be known so that such miscommunication is avoided.

32 Miller, Laura. Japanese and American indirectness. Journal of Asian Pacific Communication 1994 5(1-2): 37-55, p.52.

33 Nakane, Ikuko. Silence in intercultural communication: perceptions and performance. Philadelphia: J. Benjamins Pub. Co., 2007, p.53.

34 Nakane, Ikuko. Silence and politeness in intercultural communication in university seminars. Journal of Pragmatics 2006 38, p.1828.

35 Ibid., p.1830. 


\section{High- and Low-Context Cultures}

Differences between the Japanese and American cultural interpretations of silence can be in part explained by Hall's concept of high- and low-context communication:

A high-context (HC) communication or message is one in which most of the information is either in the physical context or internalized in the person, while very little is in the coded, explicit, transmitted part of the message. A low-context (LC) communication is just the opposite; i.e., the mass of the information is vested in the explicit code. ${ }^{36}$

The United States has a primarily low-context communication culture whereas the Japanese have a primarily high-context communication culture. Lowcontext cultures place emphasis on active verbal interaction in interpersonal relationships because low-context cultures lack group consciousness and tend to only encode meaning in verbal utterances. ${ }^{37}$ Thus, silence is not an important communication act for American English speakers. On the other hand, Japanese culture is a high-context communication culture that puts meaning into silence, which is primarily shown through the social contexts regarding Lebra's four dimensions of silence. High-context cultures tend to encode messages in the context of the verbal utterance (including the non-verbal communication) rather than the verbal utterances themselves. ${ }^{38}$ However, in typical highcontext cultures such as Japan's, silence can have ambiguous meanings, which is evident by the positive and negative emotions associated with the different dimensions of silence.

The concept of high- and low-context communication can be interpreted in terms of individualism and collectivism. According to Nishida, "individualist cultures emphasize the goals of the individual, whereas collectivist cultures stress group goals over individual goals". ${ }^{39}$ In this sense, Japan is a collectivist culture whereas America is an individualist culture. ${ }^{40}$ This is an important distinction. In an individualist society, there is a need to be accepted by others. Whereas in a collectivist society such as Japan's that has active group consciousness, there is no such need for acceptance by others. ${ }^{41}$ The Japanese expression deru kui wa utareru ${ }^{42}$ ("A tall tree catches much wind") best exemplifies this

\footnotetext{
36 Hall, Edward Twitchell. Beyond Culture. New York: Anchor Press, 1976, p.91.

37 Hall, Edward Twitchell, and Mildred Reed Hall. Hidden differences: doing business with the Japanese. Garden City, N.Y: Anchor Press, Doubleday, 1987, p.8.

38 Hall op. cit., p.101.

39 Nishida op. cit., p.108.

40 Nishida op. cit., p.109.

41 Gudykunst, William B., and Tsukasa Nishida. Bridging Japanese/North American differences. California, London, New Delhi: Sage Publications, Inc., 1994, p.51.

42 deru kui wa utareru (出る杭は打たれる): literally translated, “the stake that sticks up gets hammered down”.
} 
because it enforces the ideal that no-one should stand out from the crowd. Due to the collective group consciousness, the Japanese seek to avoid situations that involve anger, disagreement and negative emotions that could harm the group consciousness. ${ }^{43}$ Silence is thus utilised as a way of avoiding this. Consequently, through silence, one can reveal the structure of society, and the relationship between group consciousness and silence.

One needs to be aware that the characteristics of individualist and collectivist societies are not always applicable on the individual level. ${ }^{44}$ Moreover, in recent times, the younger generations of Japanese society have become more individualist than previous generations. ${ }^{45}$ This perhaps might be a signal of the growing influence of American culture in Japan. More appropriately, this might reveal how the Japanese are accommodating Western concepts such as individualism in both their culture and communication.

Nonetheless, the concept of low- and high-context cultures enables one to understand culture through silence.

\section{Private and Public Relationships}

Though high- and low-context communication it is understood that Japanese and American English speakers may use silence differently, there are also instances where these speakers use silence similarly. This is evident through the difference between public and private relationships. According to Gudykunst and Hasegawa, Americans use silence in a similar manner for both private and public relationships because "there are not major differences in Americans' communication with ingroup and outgroup members". ${ }^{46}$ Whereas for the Japanese, the behaviour of people outside of their in-group is difficult to assess and thus highly face-threatening. ${ }^{47}$ The risk of FTA is greater, so the Japanese treat silence more negatively with members of the out-group than with members of the in-group. ${ }^{48}$ This idea is related to the Japanese concept of 'uchi-soto', which emphasises that individuals should treat members of the in-group (uchi) and outgroups (soto) differently. ${ }^{49}$ This is similar to the manner in which the Americans

\footnotetext{
43 Hasegawa and Gudykunst op. cit., p.670.

44 Gudykunst, William B., Yuko Matsumoto, Stella Ting-Toomey, Tsukasa Nishida, Kim Kwangsu and Sam Heyman. The Influence of Cultural Individualism-Collectivism, Self Construals, and Individual Values on Communication Styles Across Cultures. Human Communication Research 1996 22: 510-543, p.514.

45 Dohanue, Ray T. Japanese culture and communication: critical cultural analysis. Maryland: University Press of America, 1998, p.12.

46 Hasegawa and Gudykunst op. cit., p.670.

47 Ibid.

48 Barnlund op. cit., p.117-118.

49 Nakane 2007 op. cit., p.53.
} 
utilise silence - Americans tend to reveal more of their private, inner self to members of their in-group rather than strangers. ${ }^{50,51}$ Hence, interculturally, silence is used as a communication act to limit this threat in this instance.

\section{Conclusion}

Silence is a complex phenomenon. The truthfulness traditionally associated with silence in Japan is not always reflected in the other dimensions of silence. Due to its indirectness, silence can reveal one's innermost thoughts but can also hide them, and express love but also express anger as well. This means that silence can still be highly ambiguous. Furthermore, a significant difference exists between the cultural norms regarding silence in Japanese and AngloWestern cultures, but learning to understand such differences will prevent cultural misunderstandings that could damage Japanese-Anglo-Western relations. The more one tries to understand the culture of the other, the more there will be an increased mutual awareness. The consequences are positive: better understanding leads to better communication and in an intercultural setting, more effective business dealings and learning in the classroom. More importantly, silence can provide a better understanding of not just Japanese culture but also human (verbal and non-verbal) communication and interaction as well. Not only does silence have a variety of meanings and functions, silence was shown to be a form of communication and not a lack of it. Therefore, the adage 'speech is silver, silence is golden' holds true for the Japanese.

\section{Acknowledgments}

I would like to sincerely thank Dr. Peter Hendriks, of the School of Culture, History \& Language, Australian National University, and the anonymous reviewer for their valuable comments on this paper.

\section{References}

Barlund, Dean C. Public and Private Self in Japan and the United States: Communicative Styles of Two Cultures. Tokyo: The Simul Press, 1975.

50 Hasegawa and Gudykunst op. cit., p.670.

51 Barnlund op. cit., p.34-35. 
The ANU Undergraduate Research Journal

Brown, Penelope, and Stephen C. Levinson. Politeness: some universals in language usage. Cambridge, New York: Cambridge University Press, 1987.

Davies, Roger J., and Osamu Ikeno, ed. The Japanese mind: understanding contemporary Japanese culture. Boston: Tuttle Pub., 2002.

Deal, William E. Handbook to life in medieval and early modern Japan. New York: Infobase Publishing, 2006.

Dohanue, Ray T. Japanese culture and communication: critical cultural analysis. Maryland: University Press of America, 1998.

Doi, Takei. "The Japanese Psyche: Myth and Reality". Eds. Strozier, Charles B. and Michael Flynn. Trauma and self. London: Rowman and Littlefield Publishers, Inc., 1996.

Gudykunst, William B., and Tsukasa Nishida. Bridging Japanese/North American differences. California, London, New Delhi: Sage Publications, Inc., 1994.

Gudykunst, William B., Yuko Matsumoto, Stella Ting-Toomey, Tsukasa Nishida, Kim Kwangsu and Sam Heyman. The Influence of Cultural IndividualismCollectivism, Self Construals, and Individual Values on Communication Styles Across Cultures. Human Communication Research 1996 22: 510-543.

Hall, Edward Twitchell, and Mildred Reed Hall. Hidden differences: doing business with the Japanese. Garden City, N.Y: Anchor Press, Doubleday, 1987.

Hall, Edward Twitchell. Beyond Culture. New York: Anchor Press, 1976.

Hasegawa, Tomohiro, and William B. Gudykunst. Silence in Japan and the United States. Journal of Cross-Cultural Psychology 1998 29: 668-682.

Jackson II, Ronald L. Encyclopedia of Identity. California, London, New Delhi: SAGE Publications, 2010.

Johnson M.D., Frank A. Dependency and Japanese Socialization: Psychoanalytic and Anthropological Investigations into Amae. New York and London: New York University Press, 1993.

Lebra, Takie. "The Cultural Significance of Silence in Japanese Communication". Ed. Takie Lebra. Identity, gender, and status in Japan: collected papers of Takie Lebra. Folkestone, Kent, U.K.: Global Oriental, 2007.

Lebra, Takie. Japanese Women: Constraint and Fulfillment. Honolulu: University of Hawaii Press, 1984a. 
Lebra, Takie. "Nonconfrontational Strategies for Management of Interpersonal Conflicts". Eds. Krauss, Ellis S., Thomas P. Rohlen and Patricia G. Steinhoff. Conflict in Japan. Honolulu: University of Hawaii Press, 1984b.

Maynard, Senko K. Japanese communication: language and thought in context. Honolulu: University of Hawaii Press, 1997.

Miller, Laura. Japanese and American indirectness. Journal of Asian Pacific Communication 1994 5(1-2): 37-55.

Nakane, Ikuko. Silence in intercultural communication: perceptions and performance. Philadelphia: J. Benjamins Pub. Co., 2007.

Nakane, Ikuko. Silence and politeness in intercultural communication in university seminars. Journal of Pragmatics 2006 38: 1811-1835.

Nishida, Tsukasa. "Communication in Personal Relationships in Japan". Eds. Gudykunst, William B., Stella Ting-Toomey and Tsukasa Nishida. Communication in personal relationships across cultures. California, London, New Delhi: Sage Publications, Inc., 1996.

Sifianou, Maria. "Silence and politeness". Ed. Jaworski, Adam. Silence: interdisciplinary perspectives. Berlin, New York: Mouton de Gruyter, 1997.

Wright, Dale S. Philosophical Meditations on Zen Buddhism. University Press: Cambridge, 2000.

Yamada, Haru, and Deborah Tannen. Different games, different rules: why Americans and Japanese misunderstand each other. New York, Oxford: Oxford University Press, 1997. 